\title{
Penentuan Kadar Anion dan Kation pada Air Injeksi di WTIP (Water Treatment Injection Plant) PT. Pertamina EP Asset 1 Rantau Field
}

\author{
Nurul Asmah ${ }^{1}$, Yulida Amri ${ }^{*}$, dan Rahmatul Fajri ${ }^{1}$ \\ ${ }^{1}$ Program Studi Kimia Fakultas Teknik Universitas Samudra \\ J. Meurandeh, Langsa Aceh 24416, Indonesia \\ *Corresponding author: yulidaamri@unsam.ac.id
}

\begin{abstract}
ABSTRAK
Analisis kadar kation dan anion pada air injeksi telah dilakukan. Metode yang digunakan adalah metode titrasi. Hasil pengujian diperoleh kadar $\mathrm{Ca}^{2+} 92,18 \mathrm{mg} / \mathrm{L}$, kadar $\mathrm{Mg}^{2+} 34,03 \mathrm{mg} / \mathrm{L}$, kadar $\mathrm{HCO}_{3}-1627,2 \mathrm{mg} / \mathrm{L}$, kadar $\mathrm{SO}_{4}{ }^{2-} 96,07 \mathrm{mg} / \mathrm{L}$, dan kadar $\mathrm{Cl}^{-} 6402,27 \mathrm{mg} / \mathrm{L}$. Selain itu air injeksi juga mengandung $\mathrm{CO}_{2}$ bebas sebesar $49 \mathrm{mg} / \mathrm{L}$. Berdasarkan hasil pengujian air injeksi mengandung kation yaitu $\mathrm{Ca}^{2+}, \mathrm{Mg}^{2+}$, dan anion $\mathrm{Cl}^{-}$, $\mathrm{SO}_{4}^{2-}$ dan $\mathrm{HCO}_{3}$.
\end{abstract}

Kata Kunci: Air Injeksi, WTIP, Anion, Kation

\section{PENDAHULUAN}

Rantau Field sudah mulai beroperasi sejak tahun 1928. Namun perubahan nama menjadi PT. Pertamina EP Rantau Field dilakukan pada tanggal 13 September 2005. Rantau Field memiliki luas sebesar $4.390 \mathrm{~km}^{2}$ yang berada di wilayah 2 (dua) provinsi yaitu Aceh dan Provinsi. PT. Pertamina EP Rantau Field juga berada pada dua (2) daerah kabupaten yaitu Kabupaten Aceh Tamiang dan Kabupaten Langkat [1].

PT. Pertamina EP Asset 1 Rantau Field merupakan perusahaan hulu migas yang menghasilkan produk berupa minyak mentah dengan produk samping air dan gas. Air yang digunakan di PT. Pertamina EP Asset 1 Rantau Field terlebih dahulu di olah di suatu fasilitas yang disebut Water Treatment Injection Plant (WTIP). WTIP dapat didefinisikan sebagai suatu fasilitas yang disediakan untuk proses pengolahan air. Air yang akan digunakan terlebih dahulu diolah di WTIP sehingga air yang akan digunakan memiliki kualitas sesuai aturan yang ditetapkan.

Sebagaimana diketahui air terproduksi merupakan salah satu produk samping dari PT. Pertamina EP Asset 1 Rantau Field. Air terproduksi dapat digunakan kembali setelah melalui proses treatment. Penggunaan kembali air ini tentunya akan mengurangi limbah cair yang terbuang ke lingkungan. Air terproduksi yang sudah diolah dapat kembali digunakan sebagai air injeksi. Proses injeksi air diperlukan untuk meningkatkan nilai recovery minyak. Selain itu tekanan reservoir dapat dikendalikan yang bertujuan pada peningkatan produksi minyak [2].
Oleh karena itu digunakan metode EOR (Enhanced Oil Recovery) untuk menginjeksikan bahan kimia dengan menggunakan suatu zat surfaktan. Surfaktan (Surface Active Agent) merupakan substansi yang mempunyai fungsi untuk mengubah dan mempengaruhi tegangan permukaan dan antarmuka zat cair/fluida yang tidak saling larut [3].

Proses produksi minyak bumi melibatkan perubahan suhu maupun tekanan yang mengakibatkan kesetimbangan kation dan anion yang terlarut dalam air menjadi terganggu. Akibatnya endapan atau padatan akan terbentuk. Endapan yang terbentuk ini akan mengendap pada jalur yang dilewati air injeksi yang disebut dengan scale yang mengakibatkan penurunan produksi [4]. Selain itu pipa juga akan mengalami kerusakan dengan adanya pembentukan endapan tersebut

Keberadaan kation dan anion dalam air injeksi harus diketahui jumlahnya secara kuantitatif. Oleh karena itu perlu dilakukan analisis penentuan kadar anion dan kation dalam air. Uji kualitatif dapat dilakukan dengan penambahan pereaksi spesifik yang akan menghasilkan warna pada larutan uji ataupun adanya pembentukan endapan yang sesuai dengan ciriciri ion tertentu [5]. Analisis kuantitatif dapat dilakukan dengan metode titrasi. Titrasi adalah suatu teknik analisis kuantitatif dalam penentuan konsentrasi atau kadar suatu zat dengan menggunakan larutan standar [6]. Pada studi ini akan dilakukan analisis kation dan anion dengan metode titrasi. 


\section{BAHAN DAN METODE}

\section{Bahan}

Bahan-bahan yang digunakan adalah air injeksi, aquadest $\left(\mathrm{H}_{2} \mathrm{O}\right)$, perak nitrat $\left(\mathrm{AgNO}_{3}\right) 0,1$ $\mathrm{N}$, larutan natrium hidroksida $(\mathrm{NaOH}) 0,1 \mathrm{~N}$, ammonium oksalat $\left(\mathrm{CH}_{3} \mathrm{COONH}_{4}\right)$, larutan asam asetat $\left(\mathrm{CH}_{3} \mathrm{COOH}\right)$, larutan barium klorida $\left(\mathrm{BaCl}_{2}\right) 0,05 \mathrm{~N}$, larutan asam klorida $(\mathrm{HCl}) 0,1 \mathrm{~N}$, indikator $\mathrm{K}_{2} \mathrm{Cr}_{2} \mathrm{O}_{4} 5 \%$, indikator sulfunazol, indikator calconcarbonsare, indikator EBT 0,02 $\mathrm{N}$, EDTA, indikator metil orange, indikator PP.

\section{Metode}

\section{Analisis Sulfat $\left(\mathrm{SO}_{4}{ }^{2-}\right)$}

Prosedur analisis sulfat yaitu mula-mula dimasukkan $5 \mathrm{ml}$ sampel ke dalam erlenmeyer dan ditambahkan aquadest hingga volume menjadi $100 \mathrm{ml}$. Ditambah ammonium oksalat sebanyak $1 \mathrm{ml}$ lalu ditambah $5 \mathrm{ml} \mathrm{CH}_{3} \mathrm{COOH}$ (pekat), $5 \mathrm{ml}$ aseton dan 2 tetes indikator sulfunazol. Didiamkan \pm selama 15 menit kemudian diaduk menggunakan magnetic stirrer. Selanjutnya dititrasi dengan $\mathrm{BaCl}_{2} 0,05 \mathrm{~N}$ hingga terjadi perubahan warna dari ungu menjadi biru dan dicatat volume $\mathrm{BaCl}_{2}$ yang habis terpakai.

\section{Analisis Klorida $\left(\mathrm{Cl}^{-}\right)$}

Prosedur analisis klorida yaitu dengan memipet $1 \mathrm{ml}$ sampel ke dalam erlenmeyer dan diencerkan dengan aquadest sampai volumenya menjadi $100 \mathrm{ml}$. Ditambahkan indikator $\mathrm{K}_{2} \mathrm{Cr}_{2} \mathrm{O}_{4}$ $5 \%$ secukupnya dan dititrasi dengan $\mathrm{AgNO}_{3}$ 0,1 $\mathrm{N}$ hingga warna kuning berubah menjadi merah bata kemudianvolume larutan $\mathrm{AgNO}_{3} 0,1 \mathrm{~N}$ yang habis terpakai dicatat.

\section{Analisis Kalsium $\left(\mathrm{Ca}^{2+}\right)$}

Sampel sebanyak $5 \mathrm{ml}$ dimasukkan ke dalam erlenmeyer lalu ditambahkan aquadest hingga volumenya menjadi $100 \mathrm{ml}$. Ditambah $\mathrm{NaOH} 2$ butir dan indikator calconcarbonsare. Dititrasi dengan EDTA 0,02 $\mathrm{N}$ hingga terjadi perubahan warna menjadi biru. Dicatat volume EDTA 0,02 N yang habis terpakai.

\section{Analisis Magnesium $\left(\mathrm{Mg}^{2+}\right)$}

Dimasukkan $5 \mathrm{ml}$ sampel ke dalam erlenmeyer dan ditambahkan aquadest hingga volumenya menjadi $100 \mathrm{ml}$. Ditambah larutan buffer secukupnya dan ditambah indikator EBT sebanyak 6 tetes. Larutan kemudian dititrasi menggunakan larutan EDTA 0,02 $\mathrm{N}$ sampai mengalami perubahan warna menjadi biru. Volume larutan EDTA0,02 $\mathrm{N}$ yang habis terpakai dicatat.

\section{Analisis Bikarbonat $\left(\mathrm{HCO}_{3}^{-}\right)$}

Dimasukkan $5 \mathrm{ml}$ sampel ke dalam erlenmeyer kemudian ditambahkan aquadest hingga volumenya menjadi $100 \mathrm{ml}$. Ditambah 3 tetes indikator metil orange lalu larutan dititrasi menggunakan larutan $\mathrm{HCl} 0,1 \mathrm{~N}$ hingga mengalami perubahan warna dari orange muda menjadi orange tua. Volume larutan $\mathrm{HCl} 0,1 \mathrm{~N}$ yang habis terpakai dicatat.

\section{Analisis Karbondioksida $\left(\mathrm{CO}_{2}\right)$ Bebas}

Dimasukkan $50 \mathrm{ml}$ sampel ke dalam erlenmeyer dan ditambahkan aquadest hingga volumenya menjadi $100 \mathrm{ml}$ lalu ditambahkan indikator PP (tidak terjadi perubahan warna). Kemudian dilakukan titrasi menggunakan larutan $\mathrm{NaOH} 0,1 \mathrm{~N}$ sampai terjadi perubahan warna menjadi pink. Volume $\mathrm{NaOH} 0,1 \mathrm{~N}$ yang habis terpakai dicatat.

\section{HASIL DAN PEMBAHASAN}

Tabel 1. Analisa disolved solid.

\begin{tabular}{|l|l|l|l|}
\hline \multicolumn{1}{|c|}{ Ion } & \multicolumn{1}{c|}{ Metode Analisis } & \multicolumn{1}{c|}{$\mathrm{mg} / \mathrm{L}$} & \multicolumn{1}{c|}{$\mathrm{mgeq} / \mathrm{L}$} \\
\hline Sulfat $\left(\mathrm{SO}_{4}{ }^{-}\right)$ & API RP 45 /ASTM.D-516-80 & 96,07 & 2,00 \\
\hline Klorida $(\mathrm{Cl})$ & API RP 45 / ASTM.D-512-81 & 6402,27 & 180,60 \\
\hline Kalsium $\left(\mathrm{Ca}^{2+}\right)$ & API RP 45 / ASTM.D-511-77 & 92,18 & 4,60 \\
\hline Magnesium $\left(\mathrm{Mg}^{2+}\right)$ & API RP 45 / ASTM.D-511-77 & 34,03 & 2,80 \\
\hline Bikarbonat $\left(\mathrm{HCO}_{3}-\right)$ & API RP 45 / ASTM.D-513-80 & 1627,20 & 26,67 \\
\hline
\end{tabular}

Tabel 2. Analisa kualitas air injeksi.

\begin{tabular}{|c|l|c|c|c|}
\hline Parameter & Satuan & Metode Analisa & Hasil Analisa & Baku Mutu \\
\hline $\mathrm{CO}_{2}$ bebas & $\mathrm{mg} / \mathrm{l}$ & API RP 45 & 49 & 10 \\
\hline
\end{tabular}


Pada penelitian ini dilakukan pengujian kadar anion dan kation pada air injeksi di WTIP (Water Treatment Injection Plant) PT. Pertamina EP Asset 1 Rantau Field. Dari hasil analisa disolved solid pada air injeksi didapatkan anion yaitu $\mathrm{Cl}^{-}$, $\mathrm{SO}_{4}{ }^{2-}, \mathrm{HCO}_{3}{ }^{-}$dan kation yaitu $\mathrm{Ca}^{2+}, \mathrm{Mg}^{2+}$ serta $\mathrm{CO}_{2}$ bebas.

Pada penentuan kadar sulfat dilakukan dengan cara titrasi argentometri dengan menambahkan indikator sulfanazol. Fungsi penambahan indikator adalah untuk menentukan titik ekivalen ketika dua larutan telah mencapai netralisasi dan dititrasi dengan $\mathrm{BaCl}_{2} \quad 0,05 \mathrm{~N}$ agar sulfat dapat diikat oleh ion $\mathrm{Ba}^{2+}$ hingga membentuk endapan putih yaitu $\mathrm{BaSO}_{4}$ dan terjadi perubahan warna dari ungu menjadi biru [7].

Persamaan Reaksi : $\mathrm{SO}_{4}{ }^{2-}{ }_{(\mathrm{aq})}+\mathrm{BaCl}_{2(\mathrm{aq})} \rightarrow \mathrm{BaSO}_{4(\mathrm{~s})}+2 \mathrm{Cl}^{-}{ }_{(\mathrm{aq})}$

Menurut Peraturan Menteri Lingkungan Hidup RI Nomor 01 Tahun 2010 pada Air Limbah Domestik yang belum diolah dengan kadar maksimum yang diperoleh adalah $50 \mathrm{mg} / \mathrm{L}$. Sedangkan dari tabel hasil analisis diperoleh hasil ion sulfat yaitu $96,07 \mathrm{mg} / \mathrm{L}$, hal ini menunjukkan bahwa ion sulfat yang terdapat pada air injeksi telah melebihi baku mutu standar yang telah ditetapkan. Sehingga akan menyebabkan terjadinya scale pada aliran pipa sumur injeksi. Adanya endapan atau scale yang menempel pada pipa alir akan menyebabkan kerusakan pada pipa. Scale barium sulfat sulit untuk dilarutkan, tetapi dapat di treatment dengan bahan kimia sehingga scale yang terdapat pada pipa dapat terlepas.

Penentuan kadar klorida menggunakan titrasi argentometri metode Mohr [8]. Metode ini digunakan untuk menentukan kadar klorida dalam rentang $\mathrm{pH}$ 7-10 dengan larutan standar $\mathrm{AgNO}_{3}$ dan $\mathrm{K}_{2} \mathrm{Cr}_{2} \mathrm{O}_{4} \quad 5 \%$ digunakan sebagai indikator pada saat titik akhir titrasi [9]. Titrasi dilakukan dalam suasana netral, apabila ion klorida telah habis diendapkan oleh ion perak maka ion kromat akan berwarna merah bata yang ditandai sebagai titik akhir titrasi.

Saat sebelum titik ekuivalen :

$$
\mathrm{AgNO}_{3}+\mathrm{Cl}^{-} \rightarrow \mathrm{AgCl}_{(\mathrm{s})}+\mathrm{NO}_{3}-
$$

Setelah titik ekuivalen :

$$
\mathrm{AgNO}_{3}+\mathrm{K}_{2} \mathrm{Cr}_{2} \mathrm{O}_{4} \rightarrow \mathrm{Ag}_{2} \mathrm{CrO}_{4(\mathrm{~s})}+\mathrm{NO}_{3}^{-}
$$

Menurut Peraturan Menteri Lingkungan Hidup RI Nomor 01 Tahun 2010 pada Air Limbah Domestik yang belum diolah dengan kadar maksimum yang diperoleh adalah $100 \mathrm{mg} / \mathrm{l}$. Sedangkan dari tabel hasil analisis diperoleh hasil ion klorida adalah $6402,27 \mathrm{mg} / \mathrm{L}$. Pada ion klorida ini juga melebihi baku mutu standar yang telah ditetapkan.

Pengujian kadar kalsium $\left(\mathrm{Ca}^{2+}\right)$ dilakukan menggunakan titrasi kompleksometri, Penentuan kalsium ini penting dilakukan untuk mengetahui kadar kalsium dalam air. Hal ini dikarenakan ion kalsium merupakan komponen utama dalam air injeksi yang berpengaruh terhadap pembentukan kerak pada pipa. Ion kalsium $\left(\mathrm{Ca}^{2+}+\right.$ dapat bereaksi dengan ion karbonat dan ion sulfat yang membentuk endapan tersuspensi $\left(\mathrm{CaCO}_{3}\right.$ atau $\left.\mathrm{CaSO}_{4}\right)$ yang disebut dengan scale [10]. Pada penentuan kalsium ini sampel berupa air injeksi ditambahkan indikator calconcarbonsare maka akan menimbulkan warna ungu kemudian dititrasi dengan larutan standar EDTA 0,02 $\mathrm{N}$ hingga terjadi perubahan menjadi biru sebagai titik akhir titrasi.

Penentuan magnesium $\left(\mathrm{Mg}^{2+}\right)$ dilakukan melalui titrasi kompleksometri. Titrasi kompleksometri adalah titrasi yang melibatkan pembentukan senyawa kompleks antara analit dan senyawa pengompleks. Senyawa pengompleks yang biasa digunakan adalah EDTA (Ethylenediaminetetraacetic acid). Proses titrasi magnesium juga melibatkan indikator EBT (Eriochrome Black $T$ ) dan saat dititrasi dengan EDTA $0,02 \mathrm{~N}$ maka magnesium akan membentuk suatu senyawa kompleks dengan EDTA hingga tercapai titik akhir titrasi yang ditandai dengan munculnya warna biru. Warna biru muncul setelah tercapainya titik ekivalen dimana analit $\left(\mathrm{Mg}^{2+}\right)$ sudah habis berekasi sehingga EDTA akan bereaksi dengan indikator EBT. Titrasi magnesium $\left(\mathrm{Mg}^{2+}\right)$ juga harus mengkondisikan $\mathrm{pH}$ larutan menggunakan larutan buffer. Dari hasil pengujian diperoleh kadar $\mathrm{Mg}^{2+}$ yaitu sebesar 34,03 mg/L.

Pada pengujian $\mathrm{HCO}_{3}{ }^{-}$ini menggunakan metode titrasi asidimetri yaitu titrasi dengan menggunakan larutan baku yang bersifat dalam penetapan kadar suatu zat yang bersifat asam kemudian ditambah 3 tetes indikator metil orange yang bertujuan untuk menandai titik ekivalen titrasi yang ditandai dengan perubahan warna larutan yang awalnya berwarna orange muda menjadi warna orange tua. Warna ini dikarenakan adanya pengaruh ion $\mathrm{H}^{+}$dari $\mathrm{HCl}$ yang bereaksi dengan indikator metil orange. 
Menurut Peraturan Menteri Lingkungan Hidup RI Nomor 02 Tahun 2011 Tentang Baku Mutu Air Limbah dengan kadar maksimum yang diperoleh adalah $100 \mathrm{mg} / \mathrm{l}$. Sedangkan dari tabel hasil analisis diperoleh kadar $\mathrm{HCO}_{3}{ }^{-}$adalah $1627,20 \mathrm{mg} / \mathrm{l}$. Ion bikarbonat $\left(\mathrm{HCO}_{3}^{-}\right)$yang terdapat pada air injeksi telah melebihi baku mutu standar yang telah ditetapkan. Sehingga akan menyebabkan terjadinya scale pada aliran pipa sumur injeksi. Pembentukan scale ini dipengaruhi oleh temperatur dan mengalami disosiasi pada suhu $>70^{\circ} \mathrm{C}$.

Menurut Susana (1988) pada pengujian kadar $\mathrm{CO}_{2}$ bebas ini terdapat dalam air apabila $\mathrm{pH}$ air maksimum 8,3. Pada pengujian ini menggunakan metode titrasi alkalimetri yaitu titrasi yang menggunakan larutan standar berupa basa dengan menambahkan indikator PP (fenolftalein), jika warna air berubah menjadi warna pink maka hal ini menunjukkan bahwa $\mathrm{pH}$ air lebih tinggi dari 8,3 sehingga tidak terdapat $\mathrm{CO}_{2}$ bebas. Sedangkan jika air tidak berwarna, berarti terdapat $\mathrm{CO}_{2}$ bebas. Selanjutnya air injeksi dititrasi dengan $\mathrm{NaOH} 0,1 \mathrm{~N}$ sampai berwarna pink. Dari tabel hasil analisis tersebut tidak sesuai dengan baku mutu standard yang telah ditetapkan oleh BOB BSP dan EOR PEP Jakarta, dimana baku mutu standard BOB BSP dan EOR PEP Jakarta adalah $10 \mathrm{mg} / \mathrm{L}$. Sedangkan hasil pengujian pada $\mathrm{CO}_{2}$ bebas adalah $49 \mathrm{mg} / \mathrm{L}$ [11].

\section{KESIMPULAN}

Berdasarkan hasil pengujian yang telah dilakukan dapat disimpulkan bahwa :

1. Kation yang terdapat pada air injeksi yaitu $\mathrm{Ca}^{2+}, \mathrm{Mg}^{2+}$ dan mengandung $\mathrm{CO}_{2}$ bebas.

2. Anion yang terdapat pada air injeksi yaitu $\mathrm{SO}_{4}{ }^{2-}, \mathrm{Cl}^{-}$dan $\mathrm{HCO}_{3}{ }^{-}$.

3. Kadar $\mathrm{Ca}^{2+}$ yaitu $92,18 \mathrm{mg} / \mathrm{L}$, kadar $\mathrm{Mg}^{2+}$ yaitu $34,03 \mathrm{mg} / \mathrm{l}$, kadar $\mathrm{HCO}_{3}{ }^{-}$yaitu 1627,20 $\mathrm{mg} / \mathrm{l}$, kadar $\mathrm{SO}_{4}{ }^{2-}$ yaitu $96,07 \mathrm{mg} / \mathrm{l}$, kadar $\mathrm{Cl}^{-}$ yaitu $6402,27 \mathrm{mg} / \mathrm{l}$ dan kadar $\mathrm{CO}_{2}$ yaitu 49 $\mathrm{mg} / \mathrm{l}$.

\section{UCAPAN TERIMA KASIH}

Penulis menyampaikan ucapan terima kasih terutama kepada PT.Pertamina EP Aset 1 Rantau Field atas dukungannya dalam kegiatan ini. Penulis juga berterima kasih kepada Universitas Samudra yang telah memfasilitasi terlaksananya studi ini.

\section{REFERENSI}

[1] PT.Pertamina EP Asset 1 Rantau Field. 2020. Dokumen Ringkasan Kinerja Pengelolaan Lingkungan (DRKPL). https://phe.pertamina.com/Upload/File/4211 dc45-fdb4-4a1e-bbaaddde4e45b9ffDRKPLPEPRantau2020.pdf

[2] Antara Kaltim. 2012. Memanfaatkan Air Terproduksi sebagai Media Injeksi, https://kaltim.antaranews.com/berita/8539/m emanfaatkan-air-terproduksi-sebagai-mediainjeksi\#: :text=Staff\%20Perencanaan\%20da $\mathrm{n} \% 20$ Enginering $\% 20$ Pertamina,suatu\%20su mur\%20tidak\%20cepat\%20turun.

[3] Baroroh, Umi L. U. "Diktat Kimia Dasar", Universitas Lambung Mangkurat, 2004.

[4] Ahmad, N.M dan Said, L. "Analisa Air Formasi Dalam Menentukan Kecenderungan Pembentukan Scale pada Sumur X, Y dan Z." Prosiding seminar nasional cendekiawan. 2016.

[5] Amin, M. 2016. "Analisis unsur minor kation dalam sampel air alam dengan menggunakan teknik kromatografi ion", Jurnal Techno 05 (1), 1-8 (2016).

[6] Gunawan, A dan Roeswati. "Tangkas Kimia", Kartika, Surabaya, 2004.

[7] Elviana, D., et all. 2018. "Analisis kualitatif kandungan sulfat dalam aliran air dan air danau di kawasan jakabaring sport city Palembang", ALKIMIA : Jurnal IImu Kimia Terapan 2 (2), 1-4 (2018).

[8] Alviani, S dan Amri, Y. "Analisis kuantitatif air boiler di PT. SISIRAU Aceh Tamiang", Quimica: Jurnal Kimia Sains dan Terapan 1 (2), 1-5 (2019).

[9] Ngibad, K dan Herawati, D. "Analisis kadar klorida dalam air sumur dan PDAM di desa ngelom sidoarjo", Jurnal Kimia dan Pendidikan Kimia 4(1), 1-6 (2019).

[10] Bantacut, T dan Darmanto, W. "Sifat korosif surfaktan MES (metil ester sulfonat) dari minyak sawit dalam pemilihan bahan surface facilities untuk aplikasi EOR (enhanced oil recovery)", Jurnal Teknologi Industri Pertanian 24 (2), 105-113, 2014.

[11]Susana, T. "Karbon dioksida", Oseana 12 (1), 1-11 (1988). 